\title{
立体の集合演算に用いる凸包体の生成アルゴリズムと その干渉問題への応用
}

\author{
望 月 達 也 ${ }^{* *}$ ・柚原直 弘 $^{* * *}$
}

\author{
Determining Algorithm of Three-Dimensional Convex Hull Used for Set Operations of \\ Solids and Its Application to Interference Problems*
}

Tatsuya Mochizuki** and Naohiro Yuhara***

\begin{abstract}
This paper discusses a determining algorithm for the three-dimensional convex hull which is well-fitted to deal with interference problems of solids requiring a threedimensional convex hull of a given shape for their solution and is available for set operations. The paper also deals with the application of this algorithm to specific interference problems. The proposed algorithm is devised to determine the smallest convex polyhedron containing a concave polyhedron given by a solid model beforehand, as a solid model having the same data structure as that of the concave polyhedron. It features the use of Euler operators, a general method for determining a solid model. This means that the proposed algorithm does not depend on the data structure of a solid model and that all convex polyhedrons obtained during the process of determining a three-dimensional convex hull are also in the form of solid model. Because of such a feature, the three-dimensional convex hull determined by the algorithm can be used for set operations with the given concave polyhedrons, and therefore, the algorithm provides a convenient approach to interference problems of solids requiring a threedimensional convex hull of a given shape for their solution. As an example of the application of the proposed algorithm to practical purposes, this paper also discusses a study on the extraction of undercuts in mold design using this algorithm. The findings indicate that the proposed algorithm is useful in solving such practical problems.
\end{abstract}

\section{1.はじめに}

近年，機械系 CAD では，立体の表現にソリッドモデ ル 和集合，差集合および積集合を求める立体の集合演算が 可能である. ての利点は, すでに, 形状が与えられてい る立体ど抢しの干渉（たとえば, 複数のロボットの干渉） 問題などに，利用されている.

しかしながら, 金型設計で検討される離型時の成形品 の干渉のように与えられた凹形状の立体を移動させると

* 原稿受付 1989. 8. 11

**. 静岡県工業技術センター（現在，静岡県沼津工業技術セン ター) Shizuoka Prefectural Industrial Technology Center ; Makigaya, Shizuoka 421-12, JAPAN.

*** 日本大学 理工学部 College of Science and Technology, Nihon University ; Narashinodai, Funabashi 274, JAPAN.

Key Words : three-dimensional convex hull, solid model, Euler operators, set operation, mold designing, undercut.
きに，その立体を取り囲んでいる立体と干渉する部位を， 与えられた凹形状から見つけ出す問題には，集合演算が, いまだ用いられていない。乙の種の干渉問題を取り扱う には，与えられた凹形状とその Convex Hull（凸包） 体との集合演算が有効であることを，すでに報告した2. この場合，凸包体は与えられた凹形状の立体と同じデー 夕構造をあつソリッドモデルで生成する必要がある.

凸包を求めるアルゴリズムは，乙れまでに，いくつか 報告されている ${ }^{3 \sim 8}$. それらは，与えられた点群からそ の点群を包含する最小な凸多角形や凸多面体を求めるも の, あるいは，簡単なデー夕構造をあつ凹多面体からそ の凹多面体を包含する最小な凸多面体を求めるあのであ る. これらは, ソリッドモデルのデータ構造を意識した 凸包体の生成アルゴリズムではないので，与えられた形 状の凸包体を必要とするような立体の干渉問題に適する 凸包体を効率よく生成するものではない.

そこで, 本論では, 始めに, ソリッドモデルで与えら 
れた凹形状の立体から，その形状の凸包体を，与えられ た凹形状の立体之同じデータ構造をもつッリッドモデル で生成するアルゴリズムを提案する，ついで，提案した アルゴリズムで生成した凸包体を，金型設計における干 渉問題に応用したととについて述べる.

\section{2. 凸包体の生成}

機械系 $\mathrm{CAD}$ では立体を多面体で近似することが多く みられる，それは，平面は線形多項式で表現されるので 曲面よりあ容易に図形処理が行なえることや，立体を曲 面で表現しても多面体で近似してもBoundary Representations (B-reps) $)^{9}$ と呼ばれるソリッドモデ ルを用いれば立体のトポロジカル構造がまったく同じよ うに表わせるてとなどによるからである，そこで，本論 で取り扱う立体む，多面体で近似する。

多面体を生成する操作の一つにオイラーオペレータ があり，各種の市販のソリッドモデリングシステムに用 いられている.乙れらのモデリングシステムでは, Fig. 1 亿示すように CAD のユーザが使用するコマン ドとしてオイラーオペレータを提供している．てのコマ ンドの実行に伴って, ソリッドモデルが段階的に生成さ れていく．乙のとき，ユーザはソリッドモデルのデータ 構造を意識しないでソリッドモデルを生成することがで きる. このてとがオイラーオペレータの利点の一つになっ ている. したがって，オイラーオペレータで凸包体の生 成アルゴリズムを記述しておけば，どんなデータ構造の ソリッドモデルに対しても，その生成アルゴリズムが利 用できる. よって, 本論では, 凸包体の生成にオイラー オペレータを用いる.
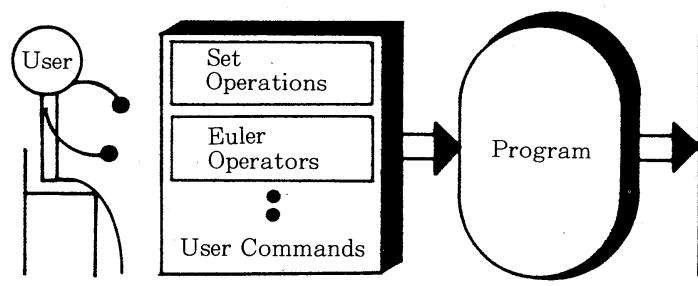

Fig. 1 Function of Euler Operator

本論では，始めに，ソリッドモデルの凹多面体が与え られる. 提案するアルゴリズムは，その凹多面体の面， 稜線および頂点の情報を用いて，凹多面体と同じデータ 構造をむつソリッドモデルで，凹多面体の凸包体（凹多 面体を包含する最小な凸多面体）を生成するあのである. 以下に, 本論で提案する凸包体の生成アルゴリズムを, Fig. 2 (a) に示す凹多面体を用いて説明する.なお，乙

† 2 面角の大きさとは, 一つの稜線を共有する二つの面（稜線 の左側と右側の面）がなす角のととである.

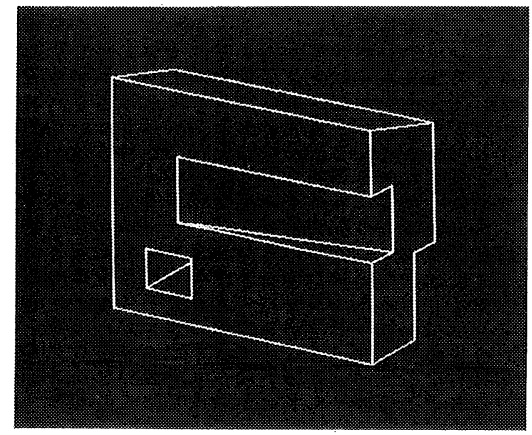

(a) Solid model

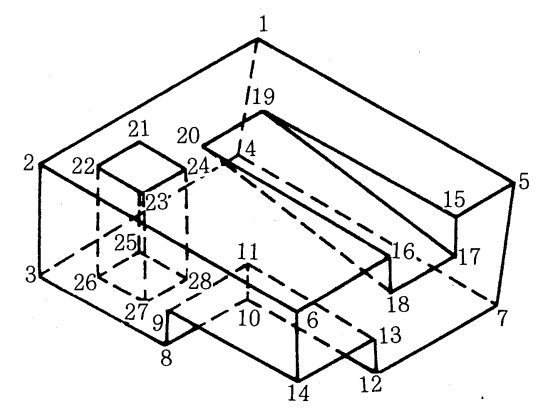

(b) Vertex number

Fig. 2 Example

こでは，凹多面体を，Fig. 3 亿示すデー夕構造をもつ ソリッドモデルで表わしてある. 図の四角はデータを, 有向線分はデータへのポインタをそれぞれ表わし, 稜線 の表現にはループへのポインタをあっている WingedEdge 法 ${ }^{11}$ を用いてある.

\section{1 凸包体の生成アルゴリズム}

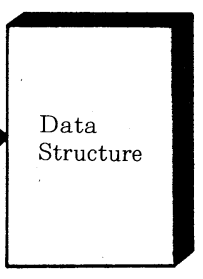

Step 1.

ソリッドモデルで与えられた凹多面体 の頂点を, 次のいずれに属するか判断し, それぞれ格納する.

Category 1.：凸包体の内部または面内 に包含されることが自明 なもの

(IV ; Set of Inside

Vertices)

Category 2.: Category1. 以外のむの

( $N V$; Set of Neutral Vertices)

集合 $I V$ の要素になるものは, 次の稜線に属する頂点 (稜線の始点亡終点)である. それは，2 面角の大きさ が形状の外側から見て $180^{\circ}$ 未満になる稜線のことであ る.

例題の形状では，頂点が次のように分類される. 数字 はFig. 2 (b) に示す頂点の番号である. 


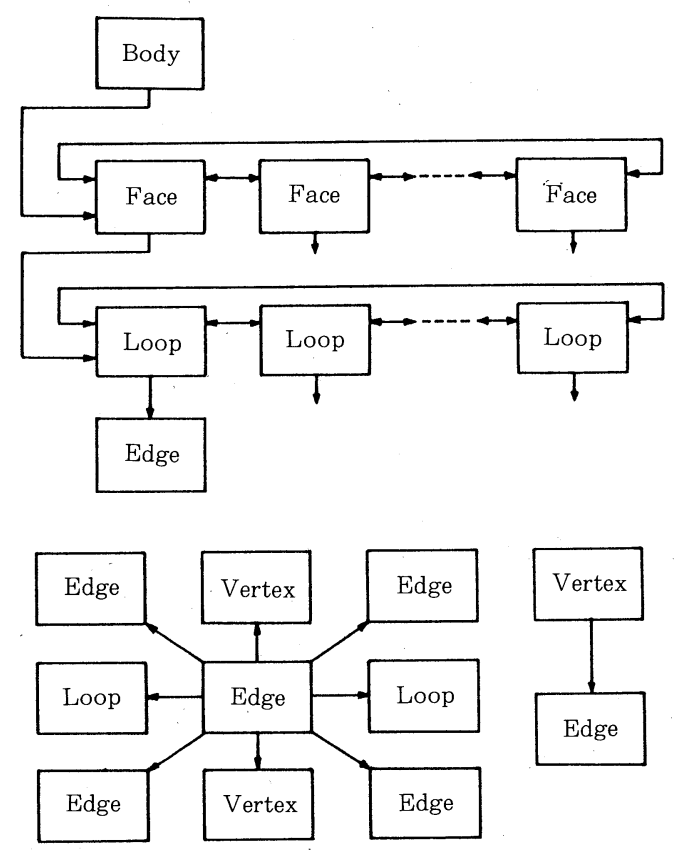

Fig. 3 Schematic diagram of extended winged-edge data structure

$$
\begin{aligned}
I V= & \{9,10,11,13,17,18,19,20,21,22,23, \\
& 24,25,26,27,28\} \\
N V= & \{1,2,3,4,5,6,7,8,12,14,15,16\}
\end{aligned}
$$

Step 2.

集合 $N V$ の中から同一平面上にない任意の 4 点を選 び，その 4 点で最初の凸多面体となる四面体を，凹多面 体と同じデータ構造をあつソリッドモデルで生成する.

Fig. 4は，乙の生成手順をオイラーオペレータで記述 したあのである.

例題では, 集合 $N V$ の 4 点 $(8,12,15$ および 16 番の 頂点）を用いて，Fig.5 に示す凸多面体（四面体）をソ
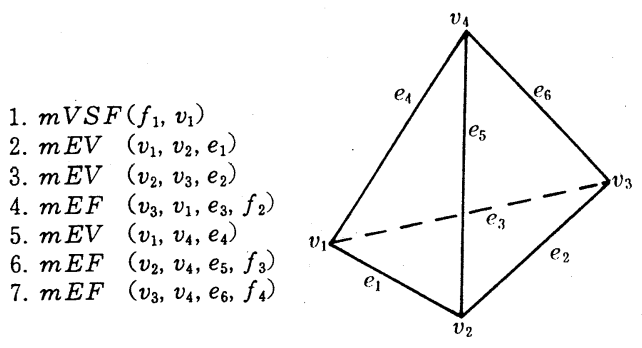

Fig. 4 Sequence for generating tetrahedron $m V S F$; make Vertex, Solid, Face $m E V$; make Edge, Vertex $m E F$; make Edge, Face

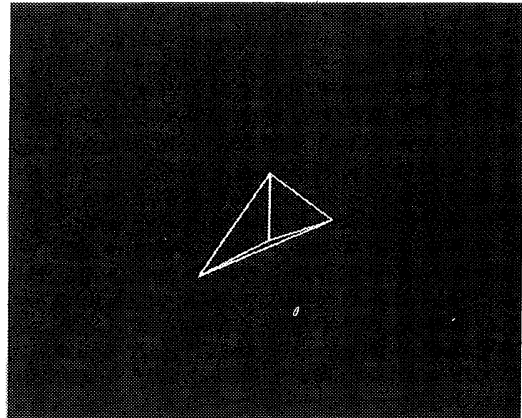

Fig. 5 Tetrahedron (step 2 in algorithm for convex hull) リッドモデルで生成している.

Step 3.

集合 $I V$ または $N V$ に格納されている頂点の中から, ソリッドモデルで生成された凸多面体の内部または面上 に位置する頂点を検出する. 検出された頂点はこれ以降 の計算に不要なものなので，集合 $I V$ または $N V$ の中 から，その頂点を削除しておく.

Step 4.

始めに集合 $N V$ の任意の頂点 $\left(v_{0}\right)$ 一つを選ぶ。 この $v_{0}$ はこれまでに生成された凸多面体の外側に位置する 点である. つぎに，その $v_{0}$ を視点とする凸多面体の投 影図を求める. それから，投影図に描かれた凸多面体の 形状データ（面, ループ, 稜線, 頂点）を操作して $v_{0}$ を頂点に含む新しい凸多面体をソリッドモデルで生成す る(この処理の詳細は次に示してある). 最後に, $v_{0}$ を 集合 $N V$ から削除する.

Step 3. と 4. は, 集合 $N V$ の要素が空になるまで繰 り返される.

例題ではFig. 6 亿示すように 8 回の乙の操作が行な われ，最終結果として Fig. 2 の凸包体が得られた.

\section{2 Step 4. の詳細説明}

ここでは，Fig. 7 亿示す流れ図を用いて, Step 4.の 詳細を説明する.

まず， $v_{0}$ を視点とする凸多面体の投影図が求められ， その投影図に描かれる凸多面体の形状データが集合 $F_{1}, F_{2}, E_{1}, E_{2}, E_{3}, V_{1}, V_{2}$ に分類される.

$$
\begin{aligned}
F_{1}= & \left\{f_{1}, f_{2}, f_{3}, f_{4}\right\} \quad k=4, F_{2}=\left\{f_{5}\right\} \quad l=1, \\
E_{1}= & \left\{e_{1}, e_{2}, e_{3}, e_{4}\right\} \quad m=4, E_{2}=\left\{e_{5}, e_{6}, e_{7}, e_{8}\right\} \\
& n=4, \\
E_{3}= & \left\{e_{9}, e_{10}, e_{11}, e_{12}\right\} \quad p=4, \\
V_{1}= & \left\{v_{1}, v_{2}, v_{3}, v_{4}\right\} \quad q=4, V_{2}=\left\{v_{5}, v_{6}, v_{7}, v_{8}\right\} \\
& r=4
\end{aligned}
$$

ここで， $F_{1}$ は投影図の輪郭線を構成する稜線を有し ている面の集合， $F_{2}$ は投影図に描かれる面の中で $F_{1}$ 

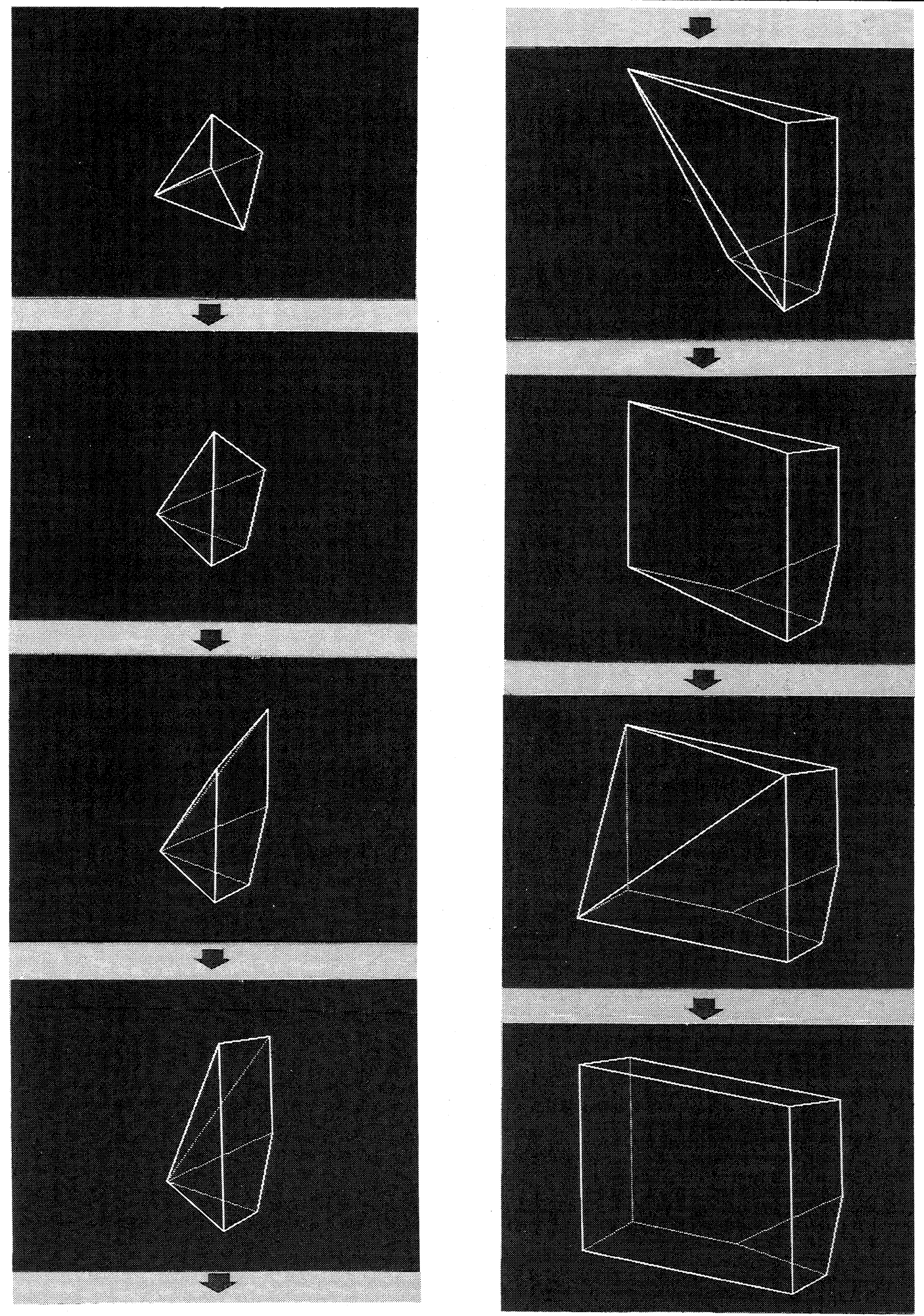

Fig. 6 Determining three-dimensional convex hull (step 3 and step 4 in algorithm for convex hull) 

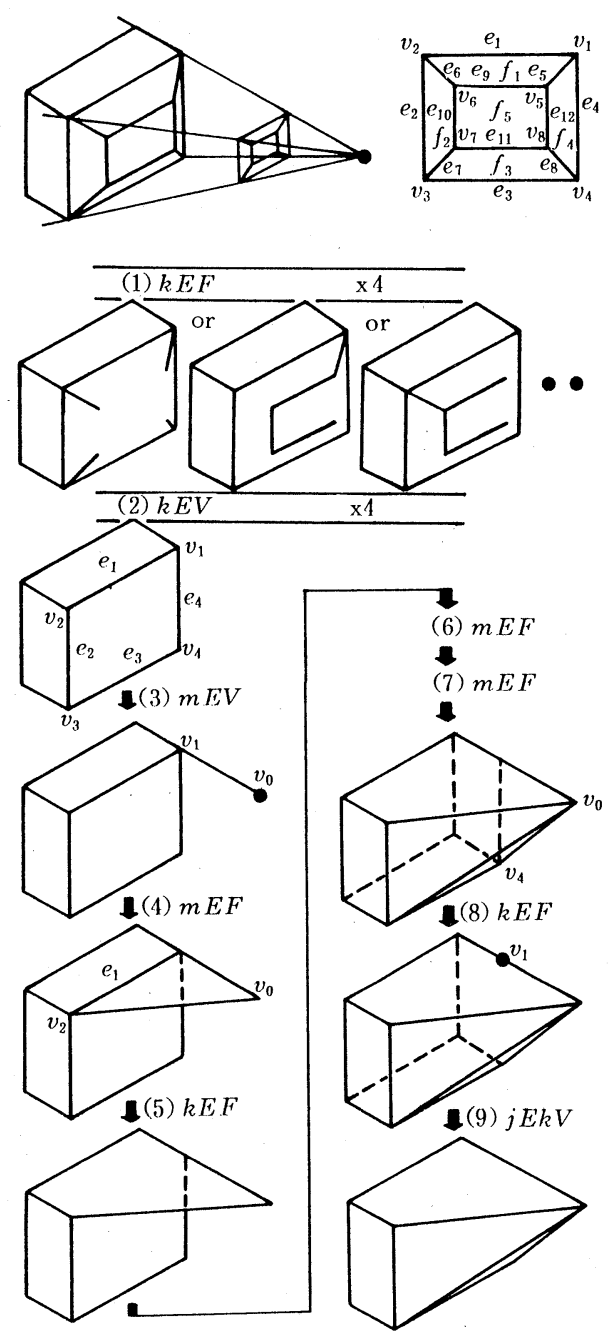

Fig. 7 Explanation of step 4 in algorithm for convex hull

に属さないものの集合， $E_{1}$ は輪郭線を構成する稜線の 集合, $E_{2}$ は輪郭線の頂点と結びついているあので $E_{1}$ には属さない稜線の集合, $E_{3}$ は投影図に描加れる稜線 の中で $E_{1}, E_{2}$ に属さないものの集合， $V_{1}$ は輪郭線に含 まれる頂点の集合， $V_{2}$ は投影図に描かれる頂点の中で $V_{1}$ に属さないあのの集合をそれぞれ表わすあのである. そして, $k, l, m, n, p, q, r$ は，それぞれ $F_{1}, F_{2}, E_{1}$, $E_{2}, E_{3}, V_{1}, V_{2}$ の要素数を表わすものである.

アルゴリズムの Step 4. は, 二つの処理部からなって いる. 一つは，投影図の輪郭線を構成しない形状デー夕 をソリッドモデルの凸多面体から削除するものである (Fig.7 の (1) と (2)). 他の一つは, 輪郭線を構成する

$\dagger$ 立体角之は, 1 点（頂点）から閉曲線上のすべての点に引い た直線によってつくられる空間の部分である.
形状データと先に選んだ $v_{0}$ とからその $v_{0}$ を頂点とする 立体角 †吕ッドモデルの凸多面体に付け加えるむの である (Fig.7の (3)〜 (9)).

第一の処理では，始めに， $E_{2}$ または $E_{3}$ に属する稜 線之その稜線を含む面をソリッドモデルの凸多面体から オイラーオペレータ $(k E F)$ でそれぞれ削除する．乙の 操作は $k+l-1$ 回繰り返されるので, 図では $k E F$ の操 作が 4 回繰り返される (Fig.7 の (1)). ソリッドモデルの 凸多面体から削除される棱線や面の順番は， $E_{2}$ または $E_{3}$ に属する稜線であればどの稜線から削除してもよい ので，図に示すような複数の結果が考えられる。なお， 削除した稜線は集合 $E_{2}$ または $E_{3}$ から，面は集合 $F_{1}$ または $F_{2}$ からそれぞれ削除しておく.

つぎに，輪郭線を構成する面，棱線および頂点だけを 残すために, $E_{2}$ または $E_{3}$ に残っている稜線之, それ らの稜線に接続している $V_{2}$ に属する頂点を, ソリッド モデルの凸多面体からオイラーオペレータ $(k E V)$ でそ れぞれ削除する. この操作は $r(=(n+p)-(k+l-1))$ 回繰り返されるので, 図では $k E V$ の操作が 4 回繰り返 される(Fig.7の (2)).ソリッドモデルの凸多面体から削 除される稜線や頂点の順番は， $E_{2}$ または $E_{3}$ に属する 稜線であればどの稜線から削除してもよい，なお，削除 した稜線は集合 $E_{2}$ または $E_{3}$ から, 頂点は集合 $V_{2}$ か らそれぞれ削除して抢く。乙こまでの操作で集合 $F_{2}, E_{2}, E_{3}$ 抢よび $V_{2}$ の要素はすべて空になり，集合 $E_{1}, V_{1}$ 抢よび $F_{1}$ の要素だけが残る. 集合 $F_{1}$ の要素数 は 1 となる。

$F_{1}=\left\{\right.$ one of $f_{1}, f_{2}, f_{3}$ and $\left.f_{4}\right\}, F_{2}=\{$ null $\}$,

$E_{1}=\left\{e_{1}, e_{2}, e_{3}, e_{4}\right\}, E_{2}=\{$ null $\}, E_{3}=\{$ null $\}$,

$V_{1}=\left\{v_{1}, v_{2}, v_{3}, v_{4}\right\}, V_{2}=\{$ null $\}$

第二の処理では，始めにオイラーオペレータ $(m E V)$ を用いて, 集合 $V_{1}$ に属する任意の頂点一つ之, 先に選 んだ $v_{0}$ とで, 新しい稜線をソリッドモデルの凸多面体 に加える (Fig.7の (3)). そして, 輪郭線を一巡する ようにオイラーオペレータ $(m E F)$ で新しい棱線と面 をそれぞれソリッドモデルの凸多面体に加えていく （Fig.7の (4)，(6) 扰よび (7)). 乙のとき，新しく生成 された面と既存の面之が，同一平面上にあり，かつ，そ の二つの面を共有する稜線の数が一つなら $k E F$, 二つ なら $k E F$ と $k E V$ の操作を行ない新しく生成した面之 その稜線をそれぞれ凸多面体から削除する（Fig.7の (5) と (8)).さらに, 複数の稜線が一直線上にあるとき は，オイラーオペレータ $(j E k V)$ を用いてそれらを一 つの稜線に合成する (Fig.7の (9)). その結果, $v_{0}$ を 頂点にあつ新しい凸多面体が生成されることになる. 
Table 1 Number of Faces, Edges and Vertices in polyhedron due to operations

\begin{tabular}{|c|c|c|c|c|c|c|c|c|c|c|c|}
\hline \multirow{2}{*}{$\begin{array}{l}\text { Topol- } \\
\text { ogical } \\
\text { Data }\end{array}$} & \multirow{2}{*}{$\begin{array}{l}\text { Existing } \\
\text { Polyhe- } \\
\text { dron }\end{array}$} & \multicolumn{9}{|c|}{ Euler Operator } & \multirow{2}{*}{$\begin{array}{l}\text { New } \\
\text { Polyhe- } \\
\text { dron }\end{array}$} \\
\hline & & $k E F \times 4$ & $k E V \times 4$ & $m E V$ & $m E F$ & $k E F$ & $m E F$ & $m E F$ & $k E F$ & $j E k V$ & \\
\hline Face & 10 & -4 & 0 & 0 & +1 & -1 & +1 & +1 & -1 & 0 & 7 \\
\hline Edge & 20 & -4 & -4 & +1 & +1 & -1 & +1 & +1 & -1 & -1 & 13 \\
\hline Vertex & 12 & 0 & -4 & +1 & 0 & 0 & 0 & 0 & 0 & -1 & 8 \\
\hline
\end{tabular}

procedure polyhedron ( $v_{0}:$ vertex);

(* $F_{1}, F_{2}$; set of faces, $E_{1}, E_{2}, E_{3}$ : set of edges,

$V_{1}, V_{2}$; set of vertices, $k, l, m, n, p, q, r ;$ number

of elements in $F_{1}, F_{2}, E_{1}, E_{2}, E_{3}, V_{1}, V_{2}$; number begin for $i:=1$ to $k+l-1$ do begin

$\left\{e, f \mid e \in\left(E_{2} \cup E_{3}\right), e \in\left(f \cap f^{*}\right)\right.$

$\left.\left.k E F(e, f) ; f^{*}\right) \in\left(F_{1} \cup F_{2}\right), f \neq f^{*}\right\}$

eliminate- $e_{-}$in $E_{2--}$ or $-E_{3},-f_{-}$in $F_{1-\text { or }}-F_{2}$; end : for $i:=1$ to $r$ do $\quad(* r=(n+p)-(k+l-1) *)$
begin

$\left\{e, v \mid\left(e, e_{1}, \cdots, e_{j}, \cdots, e_{r-i}\right) \in\left(E_{2} \cup E_{3}\right), e \neq e_{j}\right.$ $\left.v \in V_{2},(v \in e) \cap\left(v \notin e_{j}\right), j=1, \cdots, r-i\right\}$

$k E V(e, v)$;

eliminate- $e_{-}$in $-E_{2-}$ or $-E_{3},-v_{-}$in $-V_{2}$; end ;

(* eliminated data set ; $F_{2}, E_{2}, E_{3}, V_{2} *$ )

(* remained data set ; $F_{1}, E_{1}, V_{1} *$ )

$\left\{\left(v \mid v \in V_{1}\right\} \quad\right.$ generate a new polyhedron - - $\left.\quad *\right)$

$m E V\left(v_{0}, v, n e w_{-} e\right) ;\left(* n e w_{-} e ;\right.$ created edge $\left.*\right)$

$v^{*}:=v ; e^{*}:=$ new_e ; eliminate_v-in $v_{1}$;

for $i:=1$ to $q-1$ do

begin

$\left\{v \mid e \in E_{1}, v^{*} \in\left(e^{*} \cap e\right), e^{*} \neq e\right.$,

$\left.e \ni\left(v, v^{*}\right), v \neq v^{*}, v \in V_{1}\right\}$

$m E F\left(v_{0}, v\right.$, new_e, new_f $)$;

(*new-e, new-f; created edge, face, $n e w_{-} e \ni\left(v_{0}, v\right)$, new_f $\ni$ new_e $\left.*\right)$

$\left\{e_{d} \mid e_{d} \in(\right.$ new_f $f$ existed $f)$, existed $f \in$ solid, Face angle (new_f, existed_f $)=180^{\circ}$;

if $\left(e_{d}<>\right.$ null $)$

then begin

case number_of $e_{d}$ of

$1: k E F\left(e_{d}, n e w-f\right)$

2: begin

$k E F\left(e_{d 1}\right.$, new end ;

end ; $\quad\left(*\left(v \in e_{d 2}\right) \cap(v \notin e), e_{d 2} \neq e *\right)$ end :

$v^{*}:=v ; e^{*}:=n e w_{-} e ;$ eliminate_- $v_{-}$in $V_{1} ;$ end ;

$1:\left\{e, e_{r} \mid\left(e, e_{1}, \cdots, e_{r}, \cdots\right) \in\right.$ solid,

$\left.\left(e / / e_{r}\right) \cap\left(\left(e \cap e_{r}\right) \in v\right)\right\}$

if $\left(\left\{e, e_{r}\right\}<>\right.$ null $)$

then begin $j E k V\left(e, e_{r}\right)$; goto 1 ; end ;

end ;

Fig. 8 Procedure for generating polyhedron

$k E F$; kill Edge, Face

$k E V$; kill Edge, Vertex

$m E V$; make Edge, Vertex

$m E F$; make Edge, Face

$j E k V$; join Edges, kill Vertex
Fig. 8 は, アルゴリズムのStep 4.を, PASCAL 言 語の手続き文として記述したものである. 手続き文の中 では，形状データの包含関係を solid $\ni$ face $\ni$ edge $\ni$ vertexで表わしている. また, Table 1 は, Fig. 7 亿 示したオイラーオペレータの操作で生じた面, 稜線抢よ び頂点の数の増減を, オイラーオペレータの操作手順に そってまとめたものである.

本論で提案するアルゴリズムの特徴は, ソリッドモデ ルを生成するための一般的な操作法であるオイラーオぺ レータを用いていることである．乙のことは，てのアル ゴリズムが、ソリッドモデルのデータ構造に依存しない ことと，凸包体を生成する過程で得られる凸多面体すす ベてソリッドモデルになっているととを意味している. てれによって，アルゴリズムの Step 1. で分類した集合 $N V$ に属する頂点の中で, 凸包体を生成する過程で得 られる凸多面体に包含されてしまう頂点は, アルゴリズ

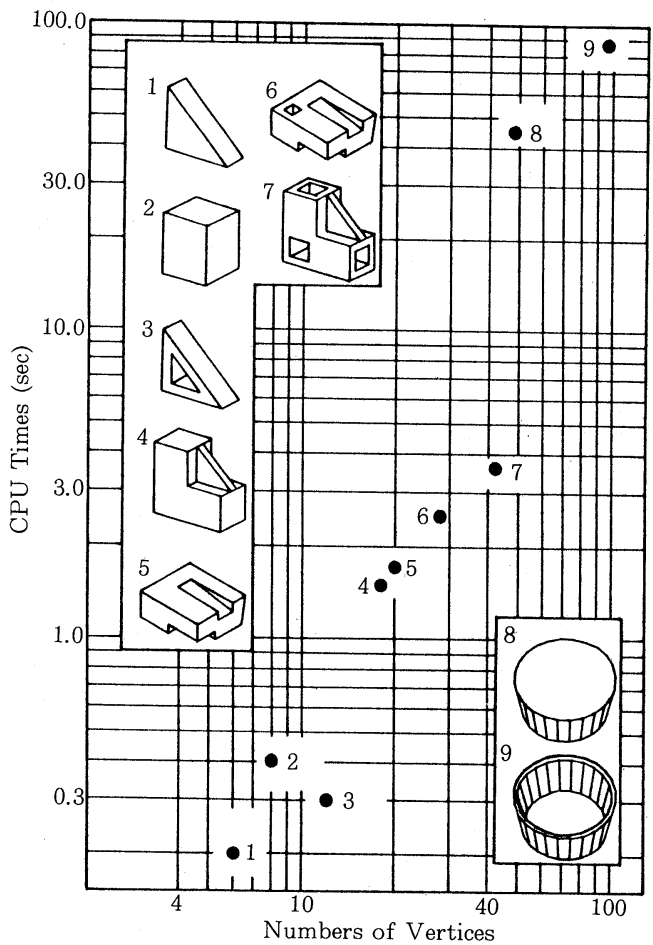

Fig. 9 CPU time versus number of vertices in polyhedron 
ムの Step 4. を操作する前に，集合 $N V$ から削除され る. このてとは, 提案するアルゴリズムが, ソリッドモ デルの凸包体を効率よく生成しているてとを意味する.

Fig. 9 は，9 個の形状の異なる凹多面体について，それ ぞれの凸包体が得られるまでの演算時間を求めたもので ある(使用計算機；HP 9000 Model 550).

\section{3. 凸包体の金型設計への応用}

金型はおも型に彫りこまれたキャビティ形状を転写す ることにより形状を造り出す成形工具であり，従来から 自動車用部品のような複雑な形状を大量に成形するのに 使用されている。複雑な形状を成形する金型の設計にお いて，最む初期に解決しておかなければならないものに 離型に扔ける金型と成形品との干渉問題がある（一般に, この干渉をアンダーカットと呼んでいる). たとえば, Fig. 10 (a) に示す把手付きコップを成形するための金 型を同図 (b), (c) のように設計すると，どちらむコッ プを金型から取り外すときに金型と干渉する部分( 网の 部分)が生ずる.

この干渉問題の解決を図るには, 同図 (d) のように 与えられた形状からアンダーカットを形成する可能性の ある部分 (以後, 潜在的アンダーカットと記す) を抽出 するととが必要である. この潜在的アンダーカットの抽 出に，本論で述べてきた凸包体を応用することができる． 以下，そのことについて述べる.

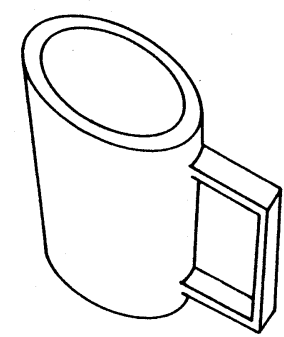

(a) Cup

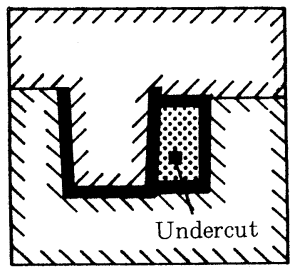

(b) Mold

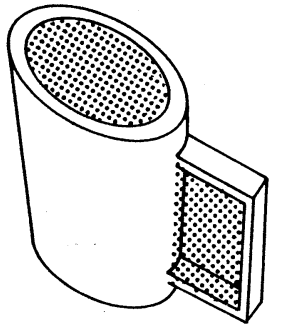

(d) Potential-undercut

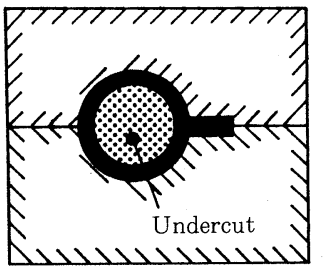

(c) Mold
Fig. 10 Undercut and potential-undercut in mold

Fig. 11 は具体的形状によって潜在的アンダーカット の抽出方法を示したものである. まず，2.の手順に従っ て形状の凸包体を求める，そして，図のように凸包体之
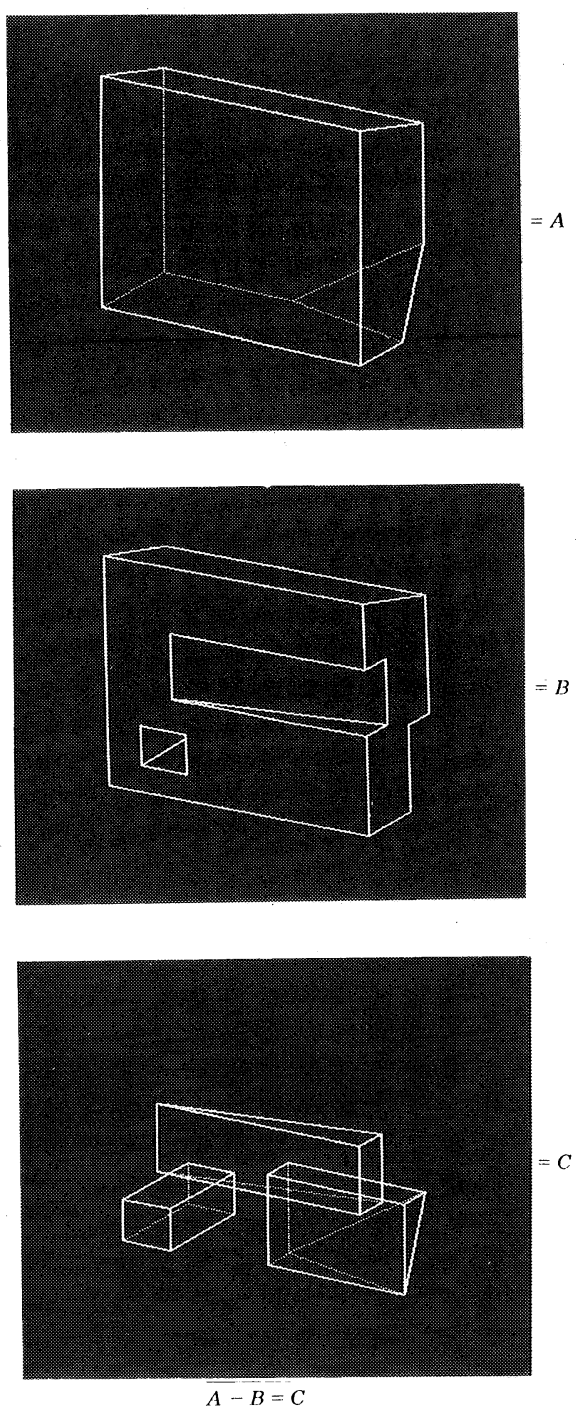

Fig. 11 Extraction of potential-undercut

与えられた形状との差集合演算を実行することで潜在的 アンダーカットが得られる.

このようにして得られた潜在的アンダーカットは金型 の一部分を構成するあのとなるので，成形品の抜き方向 に移動できる潜在的アンダーカットはアンダーカットに ならず，それ以外のあのがアンダーカットになる．乙こ で，Fig. 12 のように成形品の抜き方向を指定すると， 潜在的アンダーカットはTable 2 に示すとおり与えられ た形状と干渉せずにそれぞれ移動させることができ，ア ンダーカットが生じないてとになる，乙のととは，潜在 的アンダーカットがアンダーカットとして顕在化しなかっ たことを意味する. 


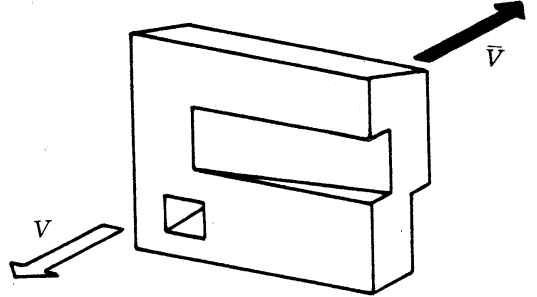

Fig. 12 Direction of withdrawal

Table 2 Result of undercut extraction

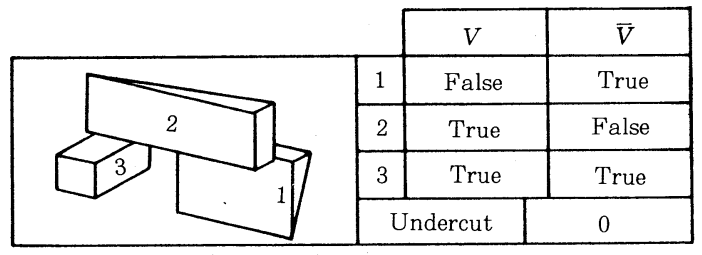

つぎに，別の形状をとりあげる. Fig. 13 に形状を, Fig. 14 にその凸包体を示す. そして，乙の凸包体と与 えられた形状との差集合演算を実行すると, Fig. 15 に 示す潜在的アンダーカットが得られる. こてで, Fig. 16 のように成形品の抜き方向を指定すると, Table 3 に示すと扣り 3 番と 4 番の潜在的アンダーカットが与え

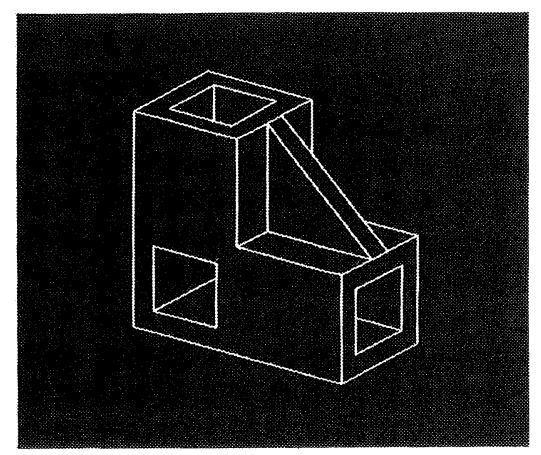

Fig. 13 Concave polyhedron

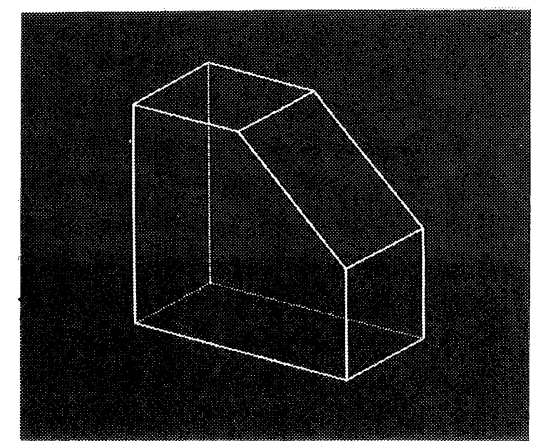

Fig. 14 Three-dimensional convex hull

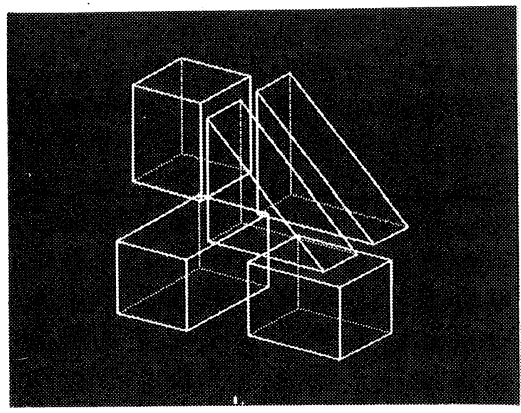

Fig. 15 Potential-undercut

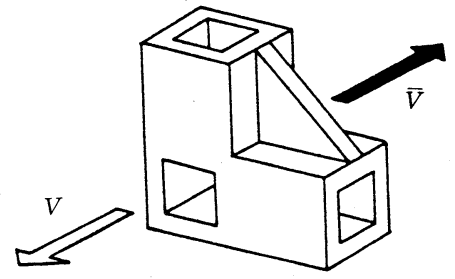

Fig. 16 Direction of withdrawal

Table 3 Result of undercut extraction

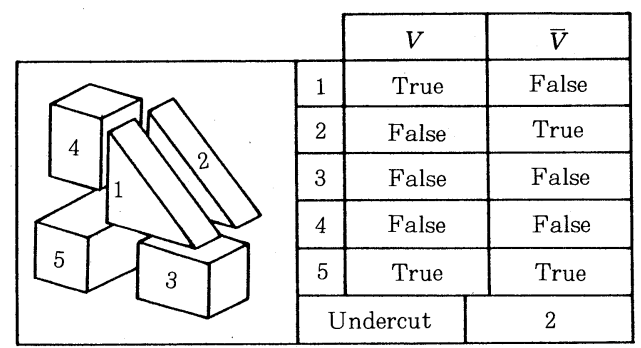

られた形状と干渉するあのとなりアンダーカットとして 顕在化する.アンダーカットになるむのは成形品を金型 から押し出す以前にシリンダやアンギュラピンなどを用 いて移動させる必要がある. そのための機構がスライド コアや割り型と呼ばれているあのである.

このようにソリッドモデルで凸包体を表現することに より，金型設計における潜在的アンダーカットが自動抽 出できる. さらに, 成形品の抜き方向を指定するてとで, 顕在化するアンダーカット屯検出できる．乙れによって, 著者らが先に報告した参考文献 12) の課題の解决が図ら れることになる.

\section{4. 結 言}

本論は，与えられた形状の凸包体を必要とするような 立体の干渉問題を取り扱うのに適する，集合演算が可能 な凸包体を生成するアルゴリズムと，そのアルゴリズム で生成した凸包体の干渉問題への応用について述べたも のである. 本論で提案するアルゴリズムは，あらかじめ ソリッドモデルで与えてある凹多面体を包含するような 
最小の凸多面体を，凹多面体と同じデータ構造をむつン リッドモデルとして生成するあのである．乙のアルゴリ ズムの特徴は，ソリッドモデルを生成するための一般的 な操作法であるオイラーオペレータを用いているてとで ある. このことは，提案するアルゴリズムが，ソリッド モデルのデータ構造に依存しないことと，凸包体を生成 する過程で得られる凸多面体あすべてソリッドモデルに なっているてとを意味している.

提案する凸包体の生成アルゴリズムは, 次の四つのス テップから構成されている. 第 1 ステップは, 凸包体の 生成に要する頂点を, 与えられた凹形状の立体から抽出 するあのである．第 2 ステップは，抽出された頂点を用 いて最初の凸多面体となる四面体をソリッドモデルで生 成するものである. 第 3 ステップは，凸包体を生成する 過程で得られた凸多面体に包含される頂点を見つけるあ のである. 第 4 ステップは, 凸包体を生成する過程で得 られた凸多面体と，その凸多面体外の一点亡から，その 一点を頂点とする新しい凸多面体をソリッドモデルで逐 次生成するものである. 第 3 と第 4 のステップは，第 1 ステップで抽出した頂点のすべてを包含する凸多面体が 得られるまで繰り返される.

本論では，提案するアルゴリズムの応用例として，金 型設計におけるアンダーカットの抽出を取り扱い, 本ア ルゴリズムの有用性を示した.

最後に，本研究を遂行するにあたり，有益な御助言を 頂きました矢崎化工株式会社の方々に謝意を表します. さらに，本論を担当された校閲委員の方には，懇切丁寧 な査読ならびに御教示をいただき，心からお礼を申しあ げます。

\section{参 考 文 献}

1)たとえば, H. B. Voelcker \& A. A. G. Requicha : Geometric Modeling of Mechanical Parts and Processes ; IEEE Computer, Vol. 10, No. 12, pp. 48〜 57(1977)

2) 望月, 柚原 : 金型設計における潜在的アンダーカットの抽 出法と最適抜き方向の決定法; 精密工学会誌, 56 巻, 3 号, pp. 491 496(1990)

3) D. R. Chand \& S. S. Kapur : An Algorithm for Convex Polytopes ; Journal of the Association for Computing Machinery, Vol. 17, No. 1, pp. 78 86 (1970)

4) R.L.Graham : An Efficient Algorithm for Determining the Convex Hull of a Finite Planar Set ; Information
Processing Letters 1, pp. 132 133 (1972)

5) R. A. Jarvis : On the Identification of the Convex Hull of a Finite Set of Points in the Plane ; Information Processing Letters 2, pp. 18 21 (1973)

6) A. Appel \& P. M. Will : Determining the Threedimensional Convex Hull of a Polyhedron ; IBM J. Res. Develop., Vol. 20, No. 6, November, pp. 590 601 (1976)

7) F. P. Preparata \& S. J. Hong : Convex Hulls of Finite Sets of Points in Two and Three Dimensions ; Communications of the ACM, Vol. 20, No.2, pp. 87 93 (1977)

8) 古川 : 3 次元空間における有限個の点の高速 Convex Hull アルゴリズム; 精密機械, 50 巻, 11 号, pp. 1771 1776 (1984)

9) A. A. G. Requicha: Representations for Rigid Solids : Theory, Methods and Systems ; Computing Surveys, Vol. 12, No. 4, pp. 437 464 (1980)

10) M. Mantyla \& R. Sulonen : GWB : A Solid Modeler with Euler Operators ; IEEE Computer Graphics \& Applications, Vol. 2, No. 7, September, pp. 17 31(1982)

11) I. C. Braid et al. : Stepwise Construction of Polyhedra in Geometric Modelling ; Mathematical Methods in Computer Graphics and Design (Ed. by K. W. Brodlie), Academic Press, pp. 123 141 (1980)

12）望月，柚原：金型仕様書作成のための意思決定支援システ ムの開発について; システム制御情報学会論文誌, 1 巻, 7 号, pp. 239 247 (1988) 